International Journal of Current Advanced Research

ISSN: O: 2319-6475, ISSN: P: 2319 - 6505, Impact Factor: SJIF: 5.995

Available Online at www.journalijcar.org

Volume 6; Issue 3; March 2017; Page No. 2684-2686

DOI: http://dx.doi.org/10.24327/ijcar.2017.2686.0076

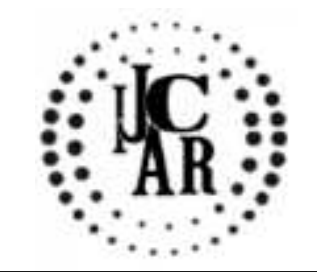

Research Article

\title{
EFFECT OF SAGE ON HYPERTENSIVE PATIENTS
}

\section{S.Vignesh and R.Gayatri Devi}

Department of physiology, Saveetha Dental College and Hospital, Chennai. 600007

\section{A R T I C L E I N F O}

\section{Article History:}

Received $27^{\text {th }}$ December, 2016

Received in revised form $5^{\text {th }}$ January, 2017

Accepted $16^{\text {th }}$ February, 2017

Published online $28^{\text {th }}$ March, 2017

\section{Key words:}

Salvia offinalis, Hypertension, Systolic and diastolic pressure.

\begin{abstract}
A B S T R A C T
Sage has been used as a traditional medicine for pain relief, protect the body from stress, free radical damages, inflammation of bacterial and viral infections. It is also used as a flovoring spices. Sage oil is also used as a carminative, antiseptic \& astringent. The aim of the study to see the effect of sage on hypertensive patients, and the main objective is to see that how does sage acts on the hypertensive patients. The study population was about 15 Hypertensive patients of age group varying from 40-55 years. Sage was given in the form of tea for 30 days .Systolic and diastolic pressure were measured before and after in take of tea by using BP apparatus. The results were obtained, systolic and diastolic pressure value shows a slight decrease from the value before intake of sage tea. So this study may help the Hypertensive patients to maintain their BP by taking sage tea.
\end{abstract}

Copyright $@ 2017$ S.Vignesh and R.Gayatri Devi. This is an open access article distributed under the Creative Commons Attribution License, which permits unrestricted use, distribution, and reproduction in any medium, provided the original work is properly cited.

\section{INTRODUCTION}

The genus Salvia, is commonly known as sage, it is the largest member of the family Laminace or the mint family which contains more than 900 species throughout the world. These plants are mostly aromatic and perennial, with flowers of different colors .Many Salvia species, including Salvia offinalis (common Sage), are the native in the Mediterranean region of Africa and some species are used worldwide for the flavoring species an also as a traditional herbal medicine [4]. Sage tea has been used for the treatment of digestive and circulatory disturbances, bronchial disease, cough and asthma hypertension and many other diseases. Salvia essential oils have been used in the treatment of wide diseases like nervous disorder, respiratory diseases, metabolic and endocrine diseases.The sage oil is also used as a carminative antiplasmodic and astringent properties.[4]

The essential oil of salvia consists of various components depending on the environmental factors. Some chemical components are flavonoids, terepenoids .essential oils are very important source in screening the activity of anticancer, anti microbial, antioxidant and scavenging activity. Salvia offinalis is considered to have more amount of essential oil compared to the other species of Salvia.[2]

One of the important components of sage is flavonoids, this is the main component which involves in the reduction of blood pressure .

\section{*Corresponding author: S.Vignesh}

Department of Physiology, Saveetha Dental College and Hospital, Chennai. 600007
Flavonoid Quercetin is the form of sage which is present, it has major effect on hypertension.Usually hypertensive patients show increased levels of plasma superoxide, hydrogen peroxide and lipid peroxide and reduced plasma levels of the antioxidant vitamin C. So flavonoid quercetin has been the main component. The daily flavonoid intake (mainly in the form of onions, apples, grapes, wine, tea, berries, herbs and spices) in the human diet is highly variable. There are many studies to see the effect of sage on different diseases over years.[5]

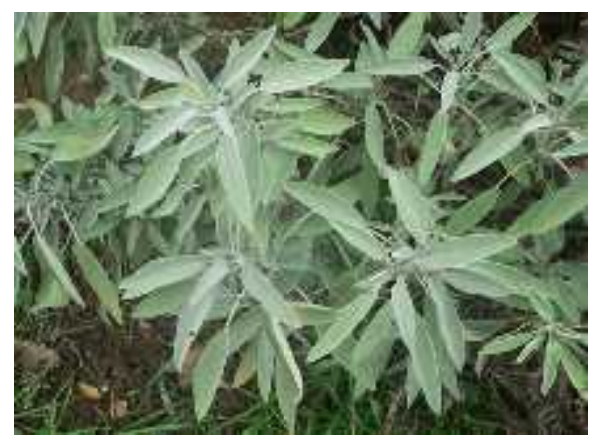<smiles>O=c1c(O)c(-c2ccc(O)c(O)c2)oc2cc(O)cc(O)c12</smiles> 


\section{MATERIALS AND METHODS}

The sage is commercially bought in the form of tea bags. A total of 15 patients $(n=15)$ suffering from hypertension were chosen. They were belonging to the age group varying from 40-55 years. These patients were given with sage tea in the morning and in the evening and asked to drink the tea for 30 days. Their blood pressure was measured before and after giving the tea by using electronic BP apparatus

\section{Inclusion Criteria:}

- The persons who had hypertension

- The persons who had high blood pressure in the range of $185 / 120 \mathrm{mmHg}$

- The people belonging to 40-55 but suffering from hypertension

- The people of Indian population

\section{Exclusion criteria:}

- People who are with blood pressure greater than 200/160 $\mathrm{mmHg}$ are not given with sage.

\section{RESULTS}

The effect of sage tea on hypertension patients was noted after 30 days. There was a significant decrease in the blood pressure of the patients. The blood pressure level has decreased very gradually. Any use of medicine can't show a immediate response. Similarly the sage also showed a mild decrease in the blood pressure. On an average the blood pressure value before giving the sage tea was found to be $159 / 88 \mathrm{mmHg}$ and after giving the sage tea gradually decreased to $155 / 86 \mathrm{~mm} \mathrm{Hg}$.

The table shows the blood pressure of each patients which has both the systolic and diastolic pressure separately noted;

\begin{tabular}{|c|c|c|c|c|}
\hline \multirow{2}{*}{ Patient no. } & \multicolumn{2}{|c|}{ Systolic Pressure } & \multicolumn{2}{|c|}{ Diastolic Pressure } \\
\hline & Before & After & Before & After \\
\hline 1 & 160 & 158 & 81 & 80 \\
\hline 2 & 147 & 146 & 78 & 79 \\
\hline 3 & 142 & 141 & 86 & 85 \\
\hline 4 & 138 & 137 & 106 & 100 \\
\hline 5 & 178 & 160 & 101 & 95 \\
\hline 6 & 164 & 164 & 79 & 80 \\
\hline 7 & 184 & 170 & 88 & 88 \\
\hline 8 & 127 & 125 & 83 & 81 \\
\hline 9 & 175 & 174 & 94 & 93 \\
\hline 10 & 156 & 154 & 84 & 82 \\
\hline 11 & 158 & 157 & 77 & 76 \\
\hline 12 & 162 & 162 & 84 & 85 \\
\hline 13 & 153 & 154 & 85 & 85 \\
\hline 14 & 167 & 165 & 99 & 85 \\
\hline 15 & 168 & 164 & 98 & 94 \\
\hline Mean & 159 & 155 & 88 & 86 \\
\hline
\end{tabular}

\section{DISCUSSION}

Over the years, the use of herbal medicines has attracted much attention in the scientific research and used in disease resistance, pharmaceutical applications due to their potential in anti hypertensive activity , anti oxidant, anti cancer of these herbal medicines. ${ }^{[7]}$

Studies shown that sage has many uses on the diseases like obesity, diabetes, hypertension, heart diseases and even cancer. ${ }^{[4]}$ In previous studies it is also shown that the sage use can reduce the hypertension and even in my study it is proven that use of sage can reduce the hypertension. There was a positive effect of sage on other diseases, as it contains many components which can reduce all those effects ${ }^{4]}$

The present study reveals that the blood pressure level has been gradually decreased by the use of sage tea .So it has shown a positive result about the effect of Sage on the hypertensive patients. ${ }^{[6]}$

The graph shows the mean values of the systolic \& diastolic pressure before and after giving the sage tea.

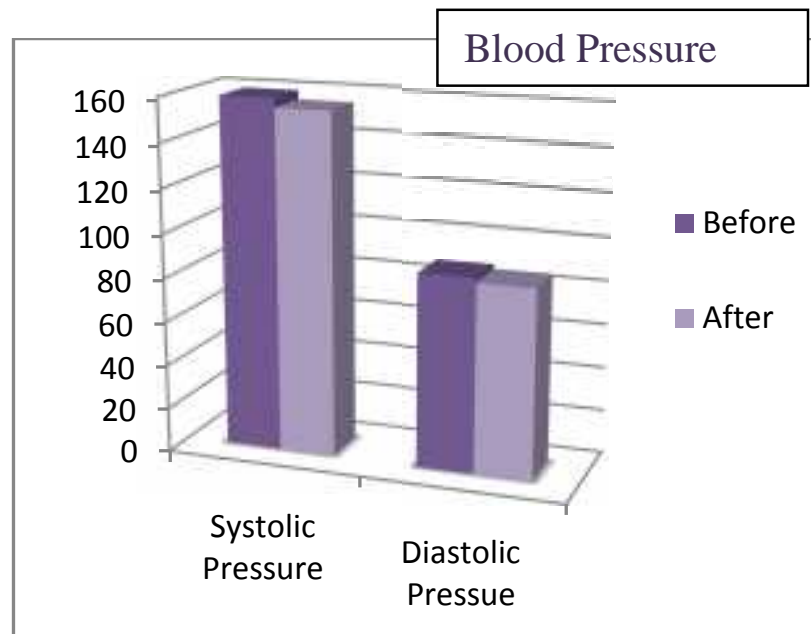

\section{CONCLUSION}

With the regards of the development of the quality of herbal medicine standardization of the extracts, phytopharmacology of different extracts, isolation and characterization of active phytopharmaceuticals, are much needed. In the changing global scenario, the interest toward plants with medicinal value is increasing substantially in the developed and in the developed and in the developing countries. This study may be very helpful for Hypertensive patients to maintain their BP by taking sage tea.

\section{References}

1. Smidling D, Mitic-Culafic D, Vukovic-Gacic B, Simic D, Knezevic-Vukcevic J. Evaluation of antiviral activity of fractionated extracts of Sage Salvia officinalis L (Lamiaceae) Arch BiolSci Belgrade. 2008;60:421-9.

2. Loizzo MR, Tundis R, Menichini F, Saab AM, Statti GA, Menichini F. Cytotoxic activity of essential oils from Labiatae and Lauraceae families against in vitro human tumor models. Anticancer Res. 2007;27:3293-[PubMed]

3. Perry NS, Bollen C, Perry EK, Ballard C. Salvia for dementia therapy: Review of pharmacologyical activity and pilot tolerability clinical trial. Pharmacol Biochem Behav. 2003;75:651-9.[PubMed]

4. Chemistry, Pharmacology, and Medicinal Property of Sage (Salvia) to Prevent and Cure Illnesses such as Obesity, Diabetes, Depression, Dementia, Lupus, Autism, Heart Disease, and Cancer

5. Juan Duarte, Raquel Pérez-Palencia, [...], and Juan TamargoAntihypertensive effects of the flavonoid quercetin in spontaneously hypertensive rats [PubMed] 
6. Sage Tea Drinking Improves Lipid Profile and Antioxidant Defences in HumansCarla M. Sá, Alice A. Ramos, [...], and Cristina Pereira-Wilson [PubMed]
7. Role of natural herbs in the treatment of hypertensionNahidaTabassum and Feroz Ahmad [PubMed]

Please cite this article in press as:

S.Vignesh and R.Gayatri Devi (2017), Effect Of Sage On Hypertensive Patients, International Journal of Current Advanced Research, 6(3), pp. 2684-2686.

http://dx.doi.org/10.24327/ijcar.2017. 2686.0076 